\title{
In Vitro Evaluation of Schistosomicidal Activity of Essential Oil of Mentha $x$ villosa and Some of Its Chemical Constituents in Adult Worms of Schistosoma mansoni
}

Authors

Affiliations
Thiago José Matos-Rocha ${ }^{1,2}$, Marilia Gabriela dos Santos Cavalcanti ${ }^{1,2}$, José Maria Barbosa-Filho ${ }^{3}$, Ana Silvia Suassuna Carneiro Lúcio ${ }^{3}$, Dyana Leal Veras ${ }^{1,2}$, Ana Paula Sampaio Feitosa ${ }^{1,2}$, José Pinto de Siqueira Júnior ${ }^{3}$, Reinaldo Nóbrega de Almeida $^{3}$, Márcia Ortiz Mayo Marques ${ }^{4}$, Luiz Carlos Alves ${ }^{1,2}$, Fábio André Brayner ${ }^{1,2}$

The affiliations are listed at the end of the article

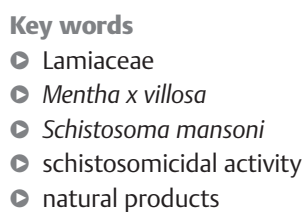

- natural products

\section{Abstract \\ $\nabla$}

This study aimed to determine the composition of the essential oil of Mentha $x$ villosa and to evaluate its biological effects in vitro on adult worms of S. mansoni. Rotundifolone (70.96\%), limonene (8.75\%), trans-caryophyllene (1.46\%), and $\beta$ pinene $(0.81 \%)$ were shown to be the major constituents of this oil. Adult worms of $S$. mansoni were incubated with different concentrations of the essential oil $(1,10,100,250,500$, and $1000 \mu \mathrm{g} / \mathrm{mL}$ ) and of its constituents rotundifolone (0.7, 3.54, 7.09, 70.96, 177.4, 354.8, and $700.96 \mu \mathrm{g} / \mathrm{mL})$, limonene $(43.75 \mu \mathrm{g} / \mathrm{mL})$, transcaryophyllene $(7.3 \mu \mathrm{g} / \mathrm{mL}), \quad$ and $\beta$-pinene
$(4.03 \mu \mathrm{g} / \mathrm{mL})$. No schistosomicidal activity was identified at the trans-caryophyllene and $\beta$ pinene concentrations studied. However, use of the essential oil $(10 \mu \mathrm{g} / \mathrm{mL})$, rotundifolone $(7.09 \mu \mathrm{g} / \mathrm{mL})$, and limonene $(43.75 \mu \mathrm{g} / \mathrm{mL})$ resulted in decreased worm motility continuing until 96 hours of observation. At higher concentrations (100 and $70.96 \mu \mathrm{g} / \mathrm{mL}$, respectively), both the essential oil and rotundifolone caused mortality among adult worms of S. mansoni. The positive control praziquantel caused the death of all parasites after $24 \mathrm{~h}$ of evaluation. The results from this study suggest that the essential oil of Mentha $x$ villosa presents schistosomicidal efficacy. received June 26,2013

revised July 3,2013

accepted July 8, 2013

\section{Bibliography}

DOI http://dx.doi.org/

10.1055/s-0033-1350732

Published online August 14, 2013

Planta Med 2013; 79 :

1307-1312 @ Georg Thieme

Verlag KG Stuttgart · New York ISSN 0032-0943

\section{Correspondence}

\section{Fábio André Brayner dos}

\section{Santos}

Molecular and Cell Biology Laboratory

Department of Parasitology Aggeu Magalhães Research Center (FIOCRUZ) and

Laboratory of Immunopathology Keizo Asami (LIKA)

Av. Moraes Rego s/n,

Campus da Universidade

Federal de Pernambuco,

50670-420 Recife, PE

Brazil

Phone: + 558121012500

Fax: + 558121012671

brayner.santos@gmail.com

\section{Introduction}

\section{$\nabla$}

For treating schistosomiasis, WHO recommends praziquantel (PZQ) because it has low toxicity and can be administered in a single dose orally. However, indiscriminate use has resulted in appearance of strains of Schistosoma mansoni (Sambon, 1907) refractory to this drug [1]. Besides praziquantel, oxamniquine is also recommended by WHO as an alternative available for treating schistosomiasis, but because of adverse effects, its use has been restricted in Brazil [2].

The search for new effective drugs for treating schistosomiasis has directed studies towards extracts and compounds isolated from plants that can provide schistosomicidal activity [3-6]. M. $x$ villosa Hudson, which is usually reported in the literature as $M$. crispa, belongs to the family Lamiaceae and is known popularly as the mintleaf-girl, creeping mint, and mint-in-pot. After identification by Dr. R. Harley, of the Royal Botanic Gardens, Kew (UK), it was shown that M. $x$ villosa is a hybrid originating from spontaneous crossing of M. spicata and M. suaveolens [7]. As for bioavail- ability, there are no studies in the literature that show bioavailability in humans or animals.

Some biological studies have been conducted to evaluate the therapeutic activity of the essential oil of M. $x$ villosa (EOMv), and these have also added information about this plant and its main compounds.

Rotundifolone $\left(\mathrm{C}_{10} \mathrm{H}_{14} \mathrm{O}_{2}\right.$; molecular weight 166) is a naturally occurring monoterpenic ketone of plant origin and an important chemical constituent of the essential oils of many Mentha species (M. rotundifolia, $M$. suaveolens, $M$. spicata, $M$. longifolia, and M. $x$ villosa) [8]. This most abundant constituent has been evaluated in relation to the following different biological activities: cardiovascular [8], hypotensive, bradycardic $[9,10]$, antimicrobial, antifungal [11], and antinociceptive [12] properties.

This study is given greater impact to rotundifolone because it represents more than $50 \%$ (can reach $65 \%$ ) of the total oil of $M . x$ villosa. It is the substance (monoterpene) present in greater amounts in the leaves of M. $x$ villosa [13-17].

The following forms of activity have been reported in the literature with regard to rotundifo- 


\begin{tabular}{|lccc|}
\hline Substance & $(\%)$ & ${ }^{*}$ KI from experiment & KI in literature* \\
\hline Sabinene & 0.23 & 972 & 976 \\
\hline$\beta$-Pinene & 0.81 & 976 & 980 \\
\hline Myrcene & 3.10 & 990 & 991 \\
\hline Limonene & 8.75 & 1029 & 1031 \\
\hline Cis- $\beta$-ocimene & 0.85 & 1035 & 1040 \\
\hline Rotundifolone & 70.96 & 1363 & 1363 \\
\hline$\beta$-Bourbonene & 0.09 & 1386 & 1384 \\
\hline$\beta$-Elemene & 0.24 & 1393 & 1391 \\
\hline Trans-caryophyllene & 1.46 & 1420 & 1418 \\
\hline$\alpha$-Humulene & 0.21 & 1454 & 1454 \\
\hline Trans- $\beta$-farnesene & 0.39 & 1457 & 1458 \\
\hline Germacrene D & 3.81 & 1481 & 1480 \\
\hline Cis-calamenene & 0.22 & 1521 & 1521 \\
\hline$\varsigma$-Elemene & 0.31 & 1523 & 1524 \\
\hline$\alpha$-Muurolol & 0.49 & 1653 & 1645 \\
\hline
\end{tabular}

Table 1 Chemical constituents of EOMv, as shown using GC-MS.

* Retention Index = Kovats Index (KI). Components are identified based on GC-MS and listed according to elution order in the column

lone: as analgesic [13], relaxative [14], hypotensive, bradycardic [15], antinociceptive [16], antimicrobial, antifungal [11], and spasmolytic [17]. Studies demonstrated a possible mechanism of action involved in the relaxative effect exhibited by rotundifolone, which they correlated with the influx of calcium channels [18].

M. $x$ villosa has been used in traditional medicine due to its antiparasitic property. It is known popularly as hortelã-rasteira (creeping mentha), hortelã comum (regular mentha), or hortelãda-folha-miúda (small-leaved mentha) [19]. Giamebil ${ }^{\circledR}$ is a commercial formulation that has as its active compound the dry extract from the leaves and stem of M. $x$ villosa, with amebicidal (Entamoeba histolytica) and giardicidal (Giardia lamblia) activities [20].

Recent studies have also demonstrated efficacy of M. $x$ villosa in Trichomonas vaginalis [21]. However, there are no published studies that show the activity of the essential oil from the leaves of M. $x$ villosa against adult worms of S. mansoni.

New molecules have been harvested from natural sources to fulfill a need for new chemical designs with distinctive pharmacological activities. The present study aimed to evaluate the in vitro effect of the essential oil of schistosomicidal M. $x$ villosa and each of its main compounds (rotundifolone, limonene, trans-caryophyllene, and $\beta$-pinene) in adult worms of S. mansoni.

\section{Results and Discussion}

$\nabla$

Several studies have shown that some natural products or compounds isolated from them present schistosomicidal activity [22-28]. Studies have also reported that some medicinal plants have been used clinically against schistosomiasis, such as myrrh $\left(\right.$ Mirazid $^{\circledR}$ ), a resinous oil obtained from Commiphora molmol (Commiphora myrrha), which is used in Egypt [29].

However, few studies in vitro have demonstrated any schistosomicidal activity of essential oils of medicinal plants against $S$. mansoni [30-33]. No work has been reported demonstrating the antiparasitic activity of EOMv and compounds isolated from it until now.

The EOMv yield was $0.1 \%$, based on the dry weight of the plant, and its composition, analyzed using GC-MS, showed the presence of nineteen substances ( $\bullet$ Table $\mathbf{1}$ ). These were identified through comparison of their spectral masses, using the GC-MS database system (Nist 62 lib.) and Kovats retention index [34]. The main compounds were: rotundifolone (70.96\%), limonene (8.75\%), trans-caryophyllene (1.46\%), and $\beta$-pinene $(0.81 \mu \mathrm{g} / \mathrm{mL})$. Antiparasitic activity of EOMv and its separate compounds against the adult worms of $S$. mansoni was observed during the biological assays in vitro. At the concentration of $100 \mu \mathrm{g} / \mathrm{mL}$, worm mortality was observed from $72 \mathrm{~h}$ onwards; at the concentration of $250 \mu \mathrm{g} / \mathrm{mL}$ from $48 \mathrm{~h}$; at the concentration of $500 \mu \mathrm{g} /$ $\mathrm{mL}$ from $24 \mathrm{~h}$, and at the concentration of $1000 \mu \mathrm{g} / \mathrm{mL}$ within $24 \mathrm{~h}$ of exposure ( Table 2 ).

Using EOMv at concentrations of 1,5 , and $10 \mu \mathrm{g} / \mathrm{mL}$, worm mortality was not observed at any of the times examined. However, in terms of relative motility at a concentration of $10 \mu \mathrm{g} / \mathrm{mL}$, minor loss of the movements of the tail, suckers, and gynaecophoric canal membrane was observed after $96 \mathrm{~h}$ of exposure.

Biological assays evaluating the essential oil of Ageratum conyzoides L. (EOAC) demonstrated that it had schistosomicidal activity on adult worms of $S$. mansoni at concentrations of 10 to $100 \mu \mathrm{g} / \mathrm{mL}$. At the concentration of $100 \mu \mathrm{g} / \mathrm{mL}$, worm mortality was observed when evaluated for up to $120 \mathrm{~h}$ [31]. Similarly to the results from the present study, the concentration of $10 \mu \mathrm{g} /$ $\mathrm{mL}$ of EOMv caused a reduction in the motor activity of adult worms and at the concentration of $100 \mu \mathrm{g} / \mathrm{mL}$, worm mortality was observed at times up to $72 \mathrm{~h}$. These results were also reported from a study on the schistosomicidal activity of the essential oil of Plectranthus neochilus (EOPn) [32].

Differently from the findings of another study in which the in vitro schistosomicidal activity of the essential oil of Piper cubeba (EOPc) was evaluated at concentrations of 12.5 and $25 \mu \mathrm{g} / \mathrm{mL}$ at $120 \mathrm{~h}$ of exposure with regard to motility, a viability similar to that of the negative control group of adult worms of S. mansoni was observed [33]. At a concentration of $100 \mu \mathrm{g} / \mathrm{mL}$, reduction in the movements of adult worms of $S$. mansoni was observed up to $72 \mathrm{~h}$. These results were superior to those observed in other studies evaluating EOAc, in which $75 \%$ mortality of the worms after this same time was reported [31].

Differently from the above results, biological assays testing the essential oil of Baccharis dracunculifolia found 100\% mortality of the worms after $24 \mathrm{~h}$ at the concentration of $10 \mu \mathrm{g} / \mathrm{mL}$ [30]. Also in this same study, $100 \%$ mortality of adult worms was demonstrated for concentrations of $250 \mu \mathrm{g} / \mathrm{mL}$ at $48 \mathrm{~h}$, and of $100 \mu \mathrm{g}$ / 


\begin{tabular}{|clll|}
\hline Groups & Incubation period $(\mathbf{h})$ & Number of dead worms (\%) & Changes in motor activity \\
\hline Control & 120 & - & +++ \\
\hline DMSO 1\% & 120 & - & +++ \\
\hline PZQ & 24 & 100 & - \\
\hline 1 & 120 & - & +++ \\
\hline 5 & 120 & - & +++ \\
\hline 10 & 96 & - & ++ \\
\hline 100 & 72 & 100 & - \\
\hline 250 & 48 & 100 & - \\
\hline 500 & 24 & 100 & - \\
\hline 1000 & 24 & 100 & - \\
\hline
\end{tabular}

Table 2 In vitro effect of different concentrations of EOMv on mortality of adult worms of S. mansoni.

Negative control (RPMI 1640; RPMI 1640 + DMSO 0.1\%); positive control with $0.5 \mathrm{\mu g} / \mathrm{mL}$. EOMv: +++ normal activity; ++ slight loss of movement, with activity of the tail, suckers, and gynaecophoric canal membrane; + movement of the tail and suckers alone; - no movement

\begin{tabular}{|llll|}
\hline Groups & Incubation period $(\mathbf{h})$ & Number of dead worms $\mathbf{( \% )}$ & Changes in motor activity \\
\hline Control & 120 & - & +++ \\
\hline DMSO $1 \%$ & 120 & - & +++ \\
\hline PZQ & 24 & 100 & - \\
\hline 0.7 & 120 & - & +++ \\
\hline 3.54 & 120 & - & +++ \\
\hline 7.09 & 96 & - & ++ \\
\hline 70.96 & 72 & 100 & - \\
\hline 177.4 & 48 & 100 & - \\
\hline 354.8 & 24 & 100 & - \\
\hline 700.96 & 24 & 100 & - \\
\hline
\end{tabular}

Table 3 In vitro effect of different concentrations of rotundifolone on mortality of adult worms of $S$. mansoni.

Negative control (RPMI 1640; DMSO + RPMI 1640); positive control with 0.5 mg/mL. Rotundifolone: +++ normal activity; ++ slight loss of movement, with activity of the tail, suckers, and gynaecophoric canal membrane; + movement of the tail and suckers alone; - no movement

\begin{tabular}{|c|c|c|c|}
\hline Groups & Incubation period $(\mathrm{h})$ & Number of dead worms (\%) & Changes in motor activity \\
\hline Control & 120 & - & +++ \\
\hline DMSO 1\% & 120 & - & +++ \\
\hline PZQ & 24 & 100 & - \\
\hline (1) $43.75 \mu \mathrm{g} / \mathrm{mL}$ & 120 & - & ++ \\
\hline (2) $7.3 \mu \mathrm{g} / \mathrm{mL}$ & 120 & - & +++ \\
\hline (3) $4.03 \mu \mathrm{g} / \mathrm{mL}$ & 120 & - & +++ \\
\hline
\end{tabular}

Table 4 In vitro effect of different concentrations of limonene (1), trans-caryophyllene (2), and $\beta$ pinene (3) on mortality of adult worms of S. mansoni.

Negative control (RPMI 1640; RPMI 1640 + DMSO 0.1\%); positive control with $0.5 \mu \mathrm{g} / \mathrm{mL}$. +++ Normal activity; ++ slight loss of movement, with activity of the tail, suckers, and gynaecophoric canal membrane; + movement of the tail and suckers alone; - no movement

$\mathrm{mL}$ at $72 \mathrm{~h}$ of observation, and similarly to our results, a dose-dependent effect was observed at the concentrations evaluated.

At the concentration of $70.96 \mu \mathrm{g} / \mathrm{mL}$, mortality and absence of movement of the worms were observed from $72 \mathrm{~h}$ onwards, at the concentration of $177.4 \mu \mathrm{g} / \mathrm{mL}$ from $48 \mathrm{~h}$, at the concentration of $354.8 \mu \mathrm{g} / \mathrm{mL}$ from $24 \mathrm{~h}$, and at the concentration of $700.96 \mu \mathrm{g} /$ $\mathrm{mL}$ within $24 \mathrm{~h}$ of exposure ( Table 3).

Using rotundifolone at concentrations of $0.7,3.54$, and $7.09 \mu \mathrm{g} /$ $\mathrm{mL}$, no worm mortality was observed at any of the times examined. Regarding motility at a concentration of $7.09 \mu \mathrm{g} / \mathrm{mL}$, minor loss of movement of the tail, suckers, and gynaecophoric canal membrane was observed after $96 \mathrm{~h}$ of exposure.

Using the limonene concentration of $43.75 \mu \mathrm{g} / \mathrm{mL}$, no worm mortality was observed at any of the times examined. In relation to motility at this concentration, decreased motor activity was ob- served after $96 \mathrm{~h}$ of exposure. The compounds $\beta$-pinene at $4.03 \mu \mathrm{g} / \mathrm{mL}$ and trans-caryophyllene at $7.3 \mu \mathrm{g} / \mathrm{mL}$ did not cause mortality of adult worms of $S$. mansoni at any time analyzed ( Table 4). Furthermore, the worms in the negative control groups (RPMI 1640 and RPMI 1640 + DMSO 1.6\%) remained viable throughout the analysis period. The positive control PZQ caused the death of all parasites after $24 \mathrm{~h}$ of evaluation, as seen in $\odot$ Tables 2, 3, and 4.

After studying the schistosomicidal effect of EOAc in that same study, the authors also evaluated the two major compounds of the essential oils precocene (I) and (E)-caryophyllene, in which schistosomicidal effects similar to that of EOAc were observed [31].

In that study, the major compound of EOMv (i.e., rotundifolone) demonstrated a schistosomicidal effect similar to EOMv [31]. 
Evaluation of the effect of other compounds (limonene, trans-caryophyllene, and $\beta$-pinene) that form part of EOMv showed that only limonene at the concentration of $43.75 \mu \mathrm{g} / \mathrm{mL}$ produced decreased motility of adult worms of $S$. mansoni. This suggests that rotundifolone is responsible for the schistosomicidal effect. On the other hand, another study showed results differing from the above in an evaluation of the biological effect of essential oil of Baccharis dracuncufolia (EOBd) on adult worms of S. mansoni. It was observed that nerolidol, the major constituent of EOBd, did not show any schistosomicidal effect on the adult worms at any of the concentrations tested [30].

The results suggest that EOMv and rotundifolone caused mortality of adult worms of S. mansoni when evaluated in vitro at concentrations greater than $10 \mu \mathrm{g} / \mathrm{mL}$ for EOMv and $7.09 \mu \mathrm{g} / \mathrm{mL}$ for rotundifolone.

In this context, the schistosomicidal activity is probably related to rotundifolone because when analyzed alone, it showed activity similar to EOMv at the respective concentration in the composition of total EOMv. The results indicate that rotundifolone can be considered to be a promising source for development of novel antischistosomal agents.

\section{Materials and Methods \\ $\nabla$ \\ Medicinal plant}

Fresh leaves of the species M. $x$ villosa were used. They were gathered from the Medicinal Plants Garden of the Pharmaceutical Technology Laboratory, Federal University of Paraíba (LTF-UFPB) between April and June 2011, where they were identified and authenticated by Dr. F.J. Abreu Matos (Laboratory of Natural Products, Federal University of Ceará) and by Dr. Raymond Harley of the Royal Botanic Gardens, Kew, England. A voucher specimen was deposited in the Prisco Bezerra Herbarium of the Federal University of Ceará (No. 14996).

\section{Extraction of the essential oil of M. $x$ villosa and analysis using GC-MS}

To extract EOMv, $10 \mathrm{~kg}$ of the leaves were steam-distilled for $8 \mathrm{~h}$. The oil obtained $(0.1 \%)$ was dried over anhydrous sodium sulfate in the usual manner and stored at $4{ }^{\circ} \mathrm{C}$ [13]. We used a gas chromatograph coupled to a mass spectrometer (Shimadzu QP-5000) under the following analytical conditions: capillary column, OV-5 (30 $\mathrm{m} \times 0.25 \mathrm{~mm} \times 0.25 \mu \mathrm{m})$; injector (Ohio Valley Specialty Chemical, Inc.), $240{ }^{\circ} \mathrm{C}$; detector, $230^{\circ} \mathrm{C}$; electron impact, $70 \mathrm{eV}$; gas drag, He; flow, $1.0 \mathrm{~mL} / \mathrm{min}$; split, $1 / 20$; program temperature, $60{ }^{\circ} \mathrm{C}-240^{\circ} \mathrm{C}$ at $3{ }^{\circ} \mathrm{C} / \mathrm{min}$; and solution injection volume, $1 \mu \mathrm{L}$ ( $1 \mu \mathrm{L}$ of essential oil per $1 \mathrm{~mL}$ of ethyl acetate). The compounds were identified by comparing their mass spectra using the GC-MS database system (Nist 62 lib.) and the Kovats retention index [34].

\section{Isolation and identification of rotundifolone}

The oil was subjected to preparative layer chromatography (Merck silica gel PF254 plates, $40 \times 20 \mathrm{~cm}$ ). The plates were eluted three times using hexane as solvent. Pure rotundifolone ( $\bullet$ Fig. 1) was obtained from the green leaves of M. $x$ villosa accordingly. The chemical purity of rotundifolone (more than $99.9 \%$ ) was determined by high-performance liquid chromatography [34].



Limonene, $\beta$-pinene, trans-caryophyllene, and praziquantel

Limonene, $\beta$-pinene, trans-caryophyllene, and praziquantel, obtained from the lower band in $99.9 \%$ purity, were purchased commercially from the company Sigma-Aldrich.

\section{Animals and parasite}

S. mansoni strain BH (Belo Horizonte) was maintained in the Schistosomiasis Laboratory of the Department of Parasitology, Oswaldo Cruz Institute, Pernambuco (FIOCRUZ-PE), using mice of Swiss Webster lineage as definitive hosts and the snail species Biomphalaria glabrata as intermediate host. Each mouse was exposed to around 120 cercariae.

Eight weeks after infection of the mice, adult worms of S. manso$n i$ were recovered from the hepatic portal system through infusion. They were washed in medium RPMI 1640, buffered with $20 \mu \mathrm{M}$ of HEPES ( $\mathrm{pH} 7.5$ ), supplemented with penicillin (100 UI/ $\mathrm{mL}$ ), streptomycin $(100 \mu \mathrm{g} / \mathrm{mL})$, and $10 \%$ fetal bovine serum (Gibco) and placed into sterile Petri dishes containing $2 \mathrm{~mL}$ of culture medium [35].

\section{In vitro antischistosomal assay}

For in vitro assay with S. mansoni, the compounds were dissolved in $100 \%$ dimethyl sulfoxide (DMSO). Each well received five worms, which were then incubated at $37^{\circ} \mathrm{C}$ in an atmosphere containing $5 \% \mathrm{CO}_{2}$. After two hours (the time allowed for the worms to adapt to the culture medium), EOMv isolates and compounds were added at a range of concentrations: a) EOMv (1.10, $100,250,500$, and $1000 \mu \mathrm{g} / \mathrm{mL})$; b) rotundifolone $(0.7,3.54$, 09.07, 70.96, 177.4, 354.8, and $700.96 \mu \mathrm{g} / \mathrm{mL})$; c) limonene $(43.75 \mu \mathrm{g} / \mathrm{mL}), \beta$-pinene $(4.03 \mu \mathrm{g} / \mathrm{mL})$, and trans-caryophyllene $(7.3 \mu \mathrm{g} / \mathrm{mL})$. As a negative control, adult worms were incubated in RPMI 1640 and RPMI $1640+1.6 \%$ DMSO. As a positive control, worms were incubated in $0.5 \mu \mathrm{g} / \mathrm{mL}$ of PZQ.

The parasites were incubated and monitored every $24 \mathrm{~h}$ until $120 \mathrm{~h}$ to evaluate changes in motor activity and consequently the mortality rate $[36,37]$. The evaluation of the viability of adult worms was based on standard procedures for screening schistosomicidal compounds used within the WHO Special Program for 
Research and Training in Tropical Diseases, in which: $(+++)$ indicates normal activity; $(++)$ slight loss of movement, with active tail, suckers, and gynaecophoric canal membrane; (+) movement of tails and suckers alone; and (-) no movement. The worms were considered to be dead when no movement was identified after 3 min of observation using an inverted microscope [38].

\section{Ethical standards}

All experiments involving the use of animals were performed in accordance to the ethical standards of Fundação Oswaldo Cruz and were approved by the ethics committee (CEUA-FIOCRUZ, No. 06/2010).

\section{Acknowledgements}

We acknowledge LTF/UFPB, LIKA/UFPE, and FIOCRUZ-PE for support for the experiments and CAPES for a scholarship.

\section{Conflict of Interest}

$\nabla$

The authors declare that there is no conflict of interest.

\section{Affiliations}

${ }^{1}$ Molecular and Cell Biology Laboratory, Department of Parasitology, Aggeu Magalhães Research Center, Oswaldo Cruz Foundation, Recife, Pernambuco, Brazil

${ }^{2}$ Keizo Asami Immunopathology Laboratory, Federal University of Pernambuco, Recife, Pernambuco, Brazil

${ }^{3}$ Federal University of Paraíba, João Pessoa, Paraíba, Brazil

${ }^{4}$ Natural Products Laboratory, Research and Development Center for Plant and Phytochemical Genetic Resources, Campinas Agronomical Institute, Campinas, São Paulo, Brazil

\section{References}

1 Abdel-Hameed ES, El-Nahas HA, Abo-Sedera SA. Antischistosomal and antimicrobial activities of some Egyptian plant species. Pharm Biol 2008; 46: 626-633

2 Liu J, Hu W, Xu B, Wang JP, Wang SQ Wang XN. Schistosomicidal mechanism of auranofin on Schistosoma japonicum and its cytotoxicity. Zhongguo Ji Sheng Chong Xue Yu Ji Sheng Chong Bing Za Zhi 2012; 30: 450-454

3 Allam G, Abuelsaad AS. In vitro and in vivo effects of hesperidin treatment on adult worms of Schistosoma mansoni. J Helminthol 2013; 9: 1-9

4 Carrara VS, Vieira SC, de Paula RG, Rodrigues V, Magalhães LG, Cortez DA, da Silva Filho AA. In vitro schistosomicidal effects of aqueous and dichloromethane fractions from leaves and stems of Piper species and the isolation of an active amide from $P$. amalago L. (Piperaceae). J Helminthol 2013; 8: 1-6

5 Ramalhete C, Magalhães LG, Rodrigues V, Mulhovo S, Silva Filho AA, Ferreira MJU. In Vitro schistosomicidal activity of Balsaminol F and Karavilagenin C. Planta Med 2012; 78: 1912-1917

6 Moraes J, Almeida AAC, Brito MRM, Marques THC, Lima TC, Sousa DP, Nakano E, Mendonça RZ, Freitas RM. Anthelmintic activity of the natural compound (+)-limonene epoxide against Schistosoma mansoni. Planta Med 2013; 79: 253-258

7 Lorenzi H, Matos FJA. Plantas medicinais no Brasil: nativas e exóticas. Nova Odessa: Instituto Plantarum; 2002

8 Lahlou S, Carneiro-Leão RFL, Leal-Cardoso JH, Toscano CF. Cardiovascular effects of the essential oil of Mentha $x$ villosa and its main constituent, piperitenone oxide, in normotensive anaesthetized rats: role of the autonomic nervous system. Planta Med 2001; 61: 638-643

9 Guedes DN, Silva DF, Barbosa-Filho JM, Medeiros IA. Calcium antagonism and the vasorelaxation of the rat aorta induced by rotundifolone. Braz J Med Biol Res 2004; 37: 1881-1887

10 Guedes DN, Silva DF, Barbosa-Filho JM, Medeiros IA. Endothelium-dependent hypotensive and vasorelaxant effects of the essential oil from aerial parts of Mentha $x$ villosa in rats. Phytomedicine 2004; 11: 490497

11 Arruda TA, Antunes RMP, Catão RMR, Lima EO, Sousa DP, Nunes XP, Pereira MSV, Barbosa-Filho JM, Cunha EMV. Estudo preliminar da atividade antimicrobiana do óleo essencial de Mentha $x$ villosa Hudson, rotundifolona e seus análogos. Rev Bras Farmacogn 2006; 16: 307-311

12 Sousa PJC, Linard CFBM, Azevedo-Batista D, Oliveira AC, Coelho-de-Souza $N A$. Antinociceptive effects of the essential oil of $M . x$ villosa leaf and its major constituent piperitone oxide in mice. Braz J Med Biol Res 2009; 42: 655-659

13 Almeida RN, Hiruma CA, Barbosa-Filho JM. Analgesic effect of rotundifolone in rodents. Fitoterapia 1996; 57: 334-338

14 Sousa PJC, Magalhães PJC, Lima CC, Oliveira VS, Leal-Cardoso JH. Effects of piperitone oxide on the intestinal smooth muscle of the guinea pig. Braz J Med Biol Res 1997; 30: 787-791

15 Guedes DN, Silva DF, Barbosa-Filho JM, Medeiros IA. Muscarinic agonist properties involved in the hypotensive and vasorelaxant responses of rotundifolone in rats. Planta Med 2002; 68: 700-704

16 Sousa DP, Júnior EVM, Oliveira FS, Almeida RN, Nunes XP, Barbosa-Filho $J M$. Antinociceptive activity of structure analogues of rotundifolone: structure-activity relationship. Z Naturforsch 2007; 62: 39-42

17 Sousa DP, Júnior GAS, Andrade LN, Calasans FR, Nunes XP, Barbosa-Filho $J M$, Batista JS. Structure and spasmolytic activity relationships of monoterpenes analogues found in many aromatic plants. Z Naturforsch 2009; 63: 808-812

18 Silva DF, Araújo IGA, Albuquerque JGF, Porto DL, Dias KLG, Cavalcante KVM, Veras RC, Nunes XP, Barbosa-Filho JM, Araújo DAM, Cruz JS, Correia $N A$, De Medeiros IA. Rotundifolone-induced relaxation is mediated by $\mathrm{BK}_{\mathrm{Ca}}$ channel activation and $\mathrm{Ca}_{\mathrm{v}}$ channel inactivation. Basic Clin Pharmacol Toxicol 2011; 109: 465-475

19 Matos FJA, Machado MI, Craveiro AA, Barbosa-Filho JM, Alencar JW, Cunha EVL, Hiruma CA. Essential oil of Mentha $x$ villosa Huds. from Northeastern Brazil. J Essent Oil Res 1999; 11: 41-44

20 Teles NSB, Fechine FV, Viana FAC, Viana IOL, Nascimento DF, Leite ALAS, Frota Bezerra FA, Moraes MO, Moraes MEA. Evaluation of the therapeutic efficacy of Mentha crispa in the treatment of giardiasis. Contemp Clin Trials 2011; 32: 809-813

21 Moraes ME, Cunha GH, Bezerra MM, Fechine FV, Pontes AV, Andrade WS, Frota Bezerra FA, Moraes MO, Cavalcanti PP. Efficacy of the Mentha crispa in the treatment of women with Trichomonas vaginalis infection. Arch Gynecol Obstet 2012; 286: 125-130

22 Magalhães LG, Machado CB, Morais ER, Moreira EBC, Soares CS, Da Silva $S H$, Da Silva Filho AA, Rodrigues V. In vitro schistosomicidal activity of curcumin against Schistosoma mansoni adult worms. Parasitol Res 2009; 104: 1197-1201

23 Fahmy ZH, El-Shennawy AM, El-Komy W, Ali E, Hamid SA. Potential antiparasitic activity of Pomegranate Extracts against schistosomules and mature worms of Schistosoma mansoni: in vitro and in vivo study. Aust J Basic Appl Sci 2009; 3: 4634-4643

24 Neves JK, Sarinho S, de Melo CM, Pereira VR, De Lima MC, Pitta IR, Albuquerque MC, Galdino SL. Immunological studies and in vitro schistosomicide action of new imidazolidine derivates. J Venom Anim Toxins Incl Trop Dis 2011; 17: 277-286

25 Moraes JD, Nascimento C, Lopes PO, Nakano E, Yamaguchi LF, Kato MJ Kawano T. Schistosoma mansoni: in vitro schistosomicidal activity of piplartine. Exp Parasitol 2011; 127: 357-364

26 Magalhães LG, Kapadia GJ, Tonuci LRS, Caixeta SC, Parreira NA, Rodrigues $V$, Da Silva Filho AA. In vitro schistosomicidal effects of some phloroglucinol derivatives from Dryopteris species against Schistosoma mansoni adult worms. Parasitol Res 2010; 106: 395-401

27 Lima CMBL, Freitas FIS, Morais LCSL, Cavalcanti MGS, Silva LF, Padilha RJR, Barbosa CGS, Santos FAB, Alves LC, Diniz MFFM. Ultrastructural study on the morphological changes to male worms of Schistosoma mansoni after in vitro exposure to allicin. Rev Soc Bras Med Trop 2011; 29: 327-330

28 Miranda MA, Magalhães LG, Tiossi RFJ, Kuehn CC, Oliveira LGR, Rodrigues $V$, McChesney JD, Bastos JK. Evaluation of the schistosomicidal activity of the steroidal alkaloids from Solanum lycocarpum fruits. Parasitol Res 2012; 111: 257-262

29 Abdul-Ghani R, Loutfy N, El-Sahn A, Hassan A. Current chemotherapy arsenal for schistosomiasis mansoni: alternatives and challenges. Parasitol Res 2009; 104: 955-965

30 Parreira NA, Magalhães LG, Moraisa DR, Caixeta SC, De Sousa, JPB, Bastos JK, Cunha WR, Silva MLA, Nanayakkara NPD, Rodrigues V, Da Silva Filho $A A$. Antiprotozoal, schistosomicidal, and antimicrobial activities of the 
essential oil from the leaves of Baccharis dracunculifolia. Chem Biodivers 2010; 7: 993-1001

31 Melo NI, Magalhães LG, Carvalho CE, Wakabayashi KAL, Aguiar GP, Ramos RC, Mantovani ALL, Turatti ICC, Rodrigues V, Groppo M, Cunha WR, Veneziani RCS, Crotti AEM. Schistosomicidal activity of the essential oil of Ageratum conyzoides L. (Asteraceae) against adult Schistosoma mansoni worms. Molecules 2011; 16: 762-773

32 Caixeta SC, Magalhães LG, Melo NI, Wakabayashi KAL, Aguiar GP, Aguiar DP, Mantovani ALL, Morais JA, Oliveira PF, Tavares DC, Gropo M, Rodrigues V, Cunha WR, Veneziani RCS, Silva Filho AA, Crotti AE. Chemical composition and in vitro schistosomicidal activity of the essential oil of Plectranthus neochilus grown in Southeast Brazil. Chem Biodivers 2011; 8: 2149-2157

33 Magalhães LG, Souza JM, Wakabayashi KAL, Caixeta SC, Laurentiz RS, Vinhólis AHC, Rezende KCS, Simaro GV, Bastos JK, Rodrigues V, Esperan$\operatorname{dim}$ VR, Ferreira DS, Crotti AEM, Cunha WR, Silva MLA. In vitro efficacy of the essential oil of Piper cubeba L. (Piperaceae) against Schistosoma mansoni adult worms. Parasitol Res 2011; 106: 395-401
34 Adams RP. Identification of essential oil components by gás chromatography/mass spectroscopy, 4th edition. Carol Stream: Allured Publ. Corp; 2007

35 Smithers SR, Terry RJ. Infection of laboratory hosts with cercarie of Schistosoma mansoni and the recovery of adult worms. Parasitology 1965; 55: 695-700

36 Almeida LMS, Farani LA, Tosta LA, Silvério MS, Sousa OV, Matos ACA, Coelho PMZ, Vasconcelos EG, Faria-Pinto P. In vitro evaluation of the schistosomicidal potential of Eremanthus erythropappus (DC) McLeisch (Asteraceae) extracts. Nat Prod Res 2011; 26: 1-7

37 Neves JK, Botelho SP, De Melo CM, Pereira VR, DE Lima MC, Pitta IR, Albuquerque MC, Galdino SL. Biological and immunological activity of new imidazolidines against adult worms of Schistosoma mansoni. Parasitol Res 2010; 107: 531-538

38 Ramirez B, Bickle Q Yousif F, Fakorede F, Mouries MA, Nwaka S. Schistosomes: challenges in compound screening. Expert Opin Drug Discov 2007; 2: 53-61 